\title{
Pengaruh Perubahan Arus Kas Dan Profitabilitas Terhadap Return Saham Pada PT Mayora Indah Tbk
}

\author{
Shinta Anggria Nur, M. Rimawan \\ Sekolah Tinggi Ilmu Ekonomi (STIE) Bima, Kota Bima Nusa Tenggara Barat ( NTB), Indonesia
}

\begin{abstract}
ABSTRAK : Kenaikan dan penurunan arus kas tiap tahun menunjukkan bahwa kinerja suatu perusahaan tidak stabil. Hal ini disertai dengan rata - rata industri rasio return on investment dibawah $30 \%$ yang artinya return on investment dalam keadaan yang tidak baik. ini disebabkan karena laba barsih yang diperoleh menurun drastis pada tahun 2014 . Penelitian ini bertujuan untuk menganalisis pengaruh perubahan arus kas dan profitabilitas terhadap return saham pada PT Mayora Indah Tbk baik secara parsial maupun simultan. Penelitian ini menggunakan pendekatan asosiatif. Populasi penelitian ini data laporan keuangan PT Mayora Indah Tbk selama 43 tahun dari tahun 1977 - 2020. Sampel penelitian ini selama 12 tahun dari tahun 2009 - 2020. Teknik pengambilan sampel dalam penelitian ini menggunakan purposive sampling. Jenis data penelitian kuantitatif dengan sumber data sekunder.Teknik analisis data menggunakan uji asumsi klasik, analisis regresi linier berganda, korelasi berganda, koefisien determinasi, uji $\mathrm{T}$ dan uji F dengan di olah menggunakan program Statistical Product and Service Solution (SPSS) version 16. Hasil penelitian ini arus kas operasi, arus kas investasi, arus kas pendanaan dan return on investment berpengaruh terhadap return saham dengan besarnya pengaruh $67,1 \%$ dan sisanya $32,9 \%$ dipengaruhi oleh faktor lain. Secara parsial hanya variabel arus kas investasi yang berpengaruh signifikan terhadap return saham sedangkan variabel arus kas operasi, arus kas pendanaan dan return on investment tidak berpengaruh terhadap return saham. Secara simultan tidak terdapat pengaruh yang signifikan variabel bebas arus kas operasi, arus kas investasi, arus kas pendanaan dan return on investment terhadap variabel terikat return saham.
\end{abstract}

Kata kunci: Arus Kas Operasi;Arus Kas Investasi;Arus Kas Pendanaan;Return On Investment;Return Saham.

\begin{abstract}
The increase and decrease in cash flow each year shows that the performance of a company is not stable. This is accompanied by the industry average return on investment ratio below $30 \%$, which means that the return on investment is not good. This is because the profit bars obtained decreased drastically in 2014. This study aims to analyze the effect of changes in cash flow and profitability on stock returns at PT Mayora Indah Tbk either partially or simultaneously. This study uses an associative approach. The population of this research is the financial statement data of PT Mayora Indah Tbk for 43 years from 1977 - 2020. The sample of this research is for 12 years from 2009 - 2020. The sampling technique in this study used purposive sampling. The type of data is quantitative research with secondary data sources. The data analysis technique uses the classical assumption test, multiple linear regression analysis, multiple correlation, the coefficient of determination, the T test and the F test using the Statistical Product and Service Solution (SPSS) version 16 program. In this study, operating cash flow, investment cash flow, funding cash flow and return on investment have an effect on stock returns with the magnitude of the effect of $67.1 \%$ and the remaining $32.9 \%$ is influenced by other factors. Partially, only the investment cash flow variable has a significant effect on stock returns, while the operating cash flow, funding cash flow and return on investment variables have no effect on stock returns. Simultaneously, there is no significant influence on the independent variable operating cash flow, investment cash flow, funding cash flow and return on investment on the dependent variable of stock returns.
\end{abstract}

Keywords: Operating Cash Flow; Investment Cash Flow; Funding Cash Flow; Return On Investment; Stock Return.

Email Address : shintaanggrianur@gmail.com 


\section{FE Universitas Maritim Raja Ali Haji}

\section{Pendahuluan}

Pembiayaan merupakan salah satu fungsi perusahaan yang penting bagi keberhasilan usaha suatu perusahaan. Fungsi ini penting karena fungsi inilah yang melakukan usaha untuk mendapatkan dana.Dana yang dibutuhkan bisa diperoleh melalui pembiayaan dari dalam perusahaan maupun pembiayaan dari luar perusahaan. Sumber pembiayaan internal berupa pemanfaatan laba yang tidak dibagikan sebagai dividen sedangkan sumber pembiayaan eksternal diperoleh perusahaan dengan melakukan pinjaman kepada pihak lain atau menjual sahamnya kepada masyarakat di pasar modal (Setyawan, 2020).

Pasar modal merupakan salah satu elemen yang menjadi tolak ukur kemajuan perekonomian suatu negara. Pengertian lain menyebutkan bahwa pasar modal merupakan suatu lembaga penyedia dana dan sarana dalam investasi. Investor melakukan kegiatan investasi untuk mendapatkan keuntungan berupa pembagian deviden dan capital gain (Muharam, 2018).

Untuk menunjang aktivitas pasar modal, diperlukan informasi tentang arus kas perusahaan. arus kas merupakan komponen penyusun laporan keuangan yang menjadi sumber informasi bagi investor dan informasi ukuran kinerja perusahaan (Pahmi, 2018). Bagi investor informasi dari laporan arus kas dapat digunakan sebagai salah satu dasar dalam pengambilan keputusan apakah investor akan membeli, menahan atau menjual surat berharga yang dimilikinya karena memperoleh return merupakan tujuan utama aktivitas perdagangan dipasar modal atas investasi yang dilakukan. Return saham disebut juga sebagai pendapatan saham yang merupakan perubahan nilai harga saham periode sekarang dengan sebelumnya yang berarti bahwa semakin tinggi perubahan harga saham maka semakin tinggi return saham yang dihasilkan. return saham dipengaruhi oleh naik turunnya harga saham suatu perusahaan.

Apabila harga saham perusahaan meningkat maka return saham akan naik dan begitupun sebaliknya. Dan jika return saham suatu perusahaan meningkat maka para investor akan tertarik untuk berinvestasi pada perusahaan tersebut (Rahayu \& Mahsuni, 2019). Return saham yang digunakan yaitu return realisasi. Return realisasi adalah return yang sudah terjadi berdasarkan data historis yang dapat digunakan sebagai salah satu pengukuran kinerja perusahaan (Endang Masitoh W., 2017).

Arus kas menyajikan sejumlah data mengenai kondisi kas perusahaan dari arus kas operasi, arus kas pendanaan dan arus kas pendanaan. arus kas operasi yaitu penghasil utama pendapatan perusahaan atau Arus kas operasi yaitu aktivitas penghasil utama pendapatan perusahaan. Dimana aktivitas operasi menentukan apakah dari operasinya perusahaan dapat menghasilkan arus kas yang cukup untuk melunasi pinjaman, memelihara kemampuan operasi perusahaan, membayar deviden dan melakukan investasi baru tanpa mengandalkan sumber pendanaan dari luar (Dasuki, 2020). Oleh karena itu, peningkatan arus kas operasi akan memberikan sinyal positif bagi investor maupun kreditor mengenai kinerja perusahaan di masa mendatang yang pada akhinya akan mempengaruhi return saham. Sehingga, semakin tinggi arus kas operasi perusahaan maka semakin tinggi kepercayaan investor pada perusahaan tersebut, sehingga semakin besar pula nilai expexted return saham dan begitupun sebaliknya (Kristanti, 2018).

Arus kas investasi yaitu aktivitas yang menyangkut perolehan dan pelepasan aktiva jangka panjang. aktivitas investasi mencakup aktivitas meminjamkan uang dan mengumpulkan piutang serta memperoleh dan menjual investasi dan aktiva yang produktif. Oleh karena itu, adanya perubahan dari aktivitas investasi akan direspon oleh investor. Akibatnya investor 
@Program Studi Manajemen

FE Universitas Maritim Raja Ali Haji

akan membeli saham perusahaan tersebut sehinngga harga saham naik dan meningkatkan juga return saham (Basuki, 2017).

Semakin menurunnya arus kas investasi menunjukkan bahwa perusahaan banyak melakukan investasi pada aset tetap atau melakukan pembelian aset investasi. sebaliknya, semakin meningkatnya arus kas investasi menujukkan perusahaan melakukan penjualan aset tetap. semakin banyak investasi yang terjadi pada perusahaan maka semakin besar pula sumber daya untuk menghasilkan pendapatan dimasa yang akan datang. Dengan demikian, investor akan tertarik untuk berinvestasi dan harga saham akan naik sehingga return saham akan naik juga (Endang Masitoh W., 2017)

Arus kas pendanaan yaitu aktivitas yang mengakibatkan perubahan modal dan pinjaman. Aktivitas pendanaan diperoleh karena adanya kegiatan peminjaman dan pembayaran hutang, perolehan sumber daya dari pemilik perusahaan serta pemberian imbalan atas investasi bagi pemilik perusahaan (Nurchayati \& Nasaroh, 2017).

Dari ketiga komponen arus kas ini investor harus bisa melihat bagaimana kemampuan perusahaan dalam menghasilkan kas yang diterima, apakah lebih banyak dihasilkan oleh kegiatan operasi atau lebih banyak didukung kegiatan investasi atau pendanaan.Kesulitan perusahaan untuk menghasilkan kas bisa mengakibatkan perusahaan diragukan keberlanjutan usahanya. dari analisis terhadap arus kas maka dapat diketahui bagaimana kondisi perusahaan tersebut (Sachiyudin, 2018).

Untuk mengukur tingkat keberhasilan suatu perusahaan dalam aktivitas investasi terdapat suatu alat analisis yaitu analisis terhadap rasio profitabilitas yang mengukur suatu perusahaan dalam menghasilkan profit. Dalam profitabilitas digunakan rasio return on investment (ROI) merupakan rasio yang menunjukkan hasil (return) atas jumlah aktiva yang digunakan dalam perusahaan. ROI juga merupakan suatu ukuran tentang efektivitas manajemen dalam mengelola investasinya. Dengan menganalisis ROI investor dapat mengukur dan menilai apakah perusahaan tersebut memanfaatkan asetnya dalam kegiatan operasional perusahaan dengan baik atau tidak. Selain itu, ROI merupakan rasio terpenting dalam rasio profitabilitas jika digunakan untuk dalam kegiatan memprediksi return saham (LUBIS, 2020). Semakin tinggi nilai Return On Investment maka semakin baik keadaan suatu perusahaan. tingginya pengembalian investasi akan dapat membuat ketertarikan bagi para investor sehingga nilai perusahaan akan meningkat dengan sendirinya seiring dengan mengalirnya uang ke perusahaan yang bersangkutan (Oktavianti, 2018).

\section{Grafik 1}

Data Empiris Arus Kas Operasi, Arus Kas Investasi dan Arus Kas Pendanaan PT Mayora Indah Tbk

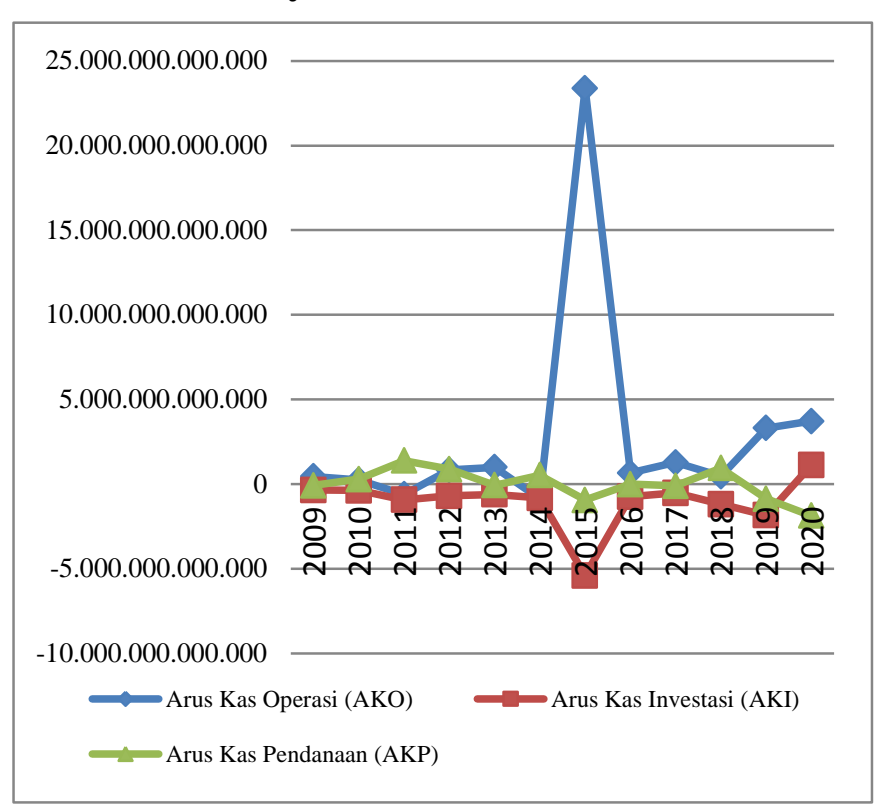

Sumber : www.idx.co.id/2021

Pada grafik diatas terlihat bahwa arus kas operasi PT Mayora Indah Tbk tiap tahun mengalami fluktuatif. Hal ini terlihat pada tahun 2020 nilai tertinggi arus kas operasi sebesar Rp 
@Program Studi Manajemen

FE Universitas Maritim Raja Ali Haji

3.715.832.449.186 dan nilai terendah pada tahun 2014 Rp 862.339.383.145. Nilai terendah arus kas operasi pada tahun 2014 dikarenakan kemampuan perusahaan dalam menciptakan laba masih rendah dan nilai arus kas operasi yang negatif menunjukkan aliran kas perusahaan yang keluar lebih besar dibanding aliran kas masuk. untuk arus kas investasi juga mengalami fluktuatif tiap tahun dengan nilai arus kas investasi yang negatif. Hal Ini disebabkan karena PT Mayora Indah Tbk mengeluarkan uang untuk investasi jangka panjang atau perusahaan sedang dalam upaya untuk melunasi pinjamannya dan membayar deviden kepada pemegang saham. untuk arus kas pendanaan mengalami fluktuatif dari beberapa tahun dengan nilai arus kas pendanaan yang negatif. Nilai arus kas pendanaan yang negatif menunjukkan bahwa PT Mayora Indah Tbk melakukan pembayaran deviden dan pengurangan jumlah utang. Sehingga, kenaikan dan penurunan arus kas operasi, arus kas investasi dan arus kas pendanaan tiap tahun menunjukkan bahwa kinerja perusahaan tidak stabil.

Berdasarkan uraian di atas maka peneliti tertarik untuk melakukan penelitian dengan judul : "PENGARUH PERUBAHAN ARUS KAS DAN PROFITABILITAS TERHADAP RETURN SAHAM PADA PT MAYORA INDAH TBK".

\section{Rumusan Masalah}

1. Adakah pengaruh yang signifikan secara parsial antara Arus Kas Operasi (AKO) terhadap Return Saham pada PT Mayora Indah Tbk Tahun 20092020 ?

2. Adakah pengaruh yang signifikan secara parsial antara Arus Kas Investasi (AKI) terhadap Return Saham pada PT Mayora Indah Tbk Tahun 2009-2020 ?

3. Adakah pengaruh yang signifikan secara parsial antara Arus Kas Pendanaan (AKP) terhadap Return Saham pada PT Mayora Indah Tbk Tahun 2009-2020?
4. Adakah pengaruh yang signifikan secara parsial antara Return On Investment (ROI) terhadap Return Saham pada PT Mayora Indah Tbk Tahun 2009-2020 ?

5. Adakah pengaruh yang signifikan secara simultan antara Arus Kas Operasi (AKO), Arus Kas Investasi (AKI), Arus Kas Pendanaan (AKP) dan Return On Investment (ROI) terhadap Return Saham pada PT Mayora Indah Tbk Tahun 2009-2020?

\section{Tujuan Penelitian}

Pertama, Untuk menguji dan menganalisis ada tidaknya pengaruh yang signifikan secara parsial antara Arus Kas Operasi (AKO),Arus Kas Investasi (AKI), Arus Kas Pendanaan (AKP) dan Return On Investment (ROI) terhadap Return Saham pada PT Mayora Indah Tbk.

Kedua, Untuk menguji dan menganalisis ada tidaknya pengaruh yang signifikan secara simultan antara Arus Kas Operasi (AKO), Arus Kas Investasi (AKI), Arus Kas Pendanaan (AKP) dan Return On Investment (ROI) terhadap Return Saham pada PT Mayora Indah Tbk.

\section{Manfaat Penelitian}

Pertama, Penelitian ini dapat dijadikan sebagai bahan masukan yang dapat menambah informasi dalam pengambilan keputusan untuk menentukan return saham didalam suatu perusahaan.

Kedua, Sebagai bahan dasar bagi penelitian selanjutnya khususnya peneliti yang meneliti tentang pengaruh arus kas dan profitabilitas terhadap return saham. 


\section{Metode Penelitian}

Jenis Penelitian

Penelitian ini termasuk penelitian asosiatif. Penelitian asosiatif merupakan penelitian yang bertujuan untuk mengetahui hubungan antara dua variabel atau lebih. Penelitian ini mencari pengaruh antara Arus Kas Operasi (X1), Arus Kas Investarsi (X2), Arus Kas Pendanaan (X3) dan Return On Investment (X4) sebagai variabelrr bebas dengan Return Saham (Y) sebagai variabel terikat.

\section{Waktu}

Penelitian dilaksanakan selama 3 bulan dari bulan februari 2021 sampai dengan bulan april 2021.

\section{Lokasi}

Lokasi penelitian ini dilakukan di PT Mayora Indah Tbk yang beralamat di Gedung Mayora Jl. Tomang Raya Kav 21 - 23, Jakarta Barat.

\section{Populasi dan Sampel}

Adapun populasi dalam penelitian ini yaitu laporan keuangan PT Mayora Indah Tbk selama 42 tahun (1977 - 2019). Sedangkan sampel adalah laporan keuangan PT Mayora Indah Tbk selama 7 tahun yaitu dari tahun 2013 - 2019 . Dengan teknik sampling yang digunakan adalah Purposive Sampling. Purposive Sampling adalah teknik penentuan sampel dengan pertimbangan tertentu. Adapun alasan menggunakan teknik sampling ini yaitu ketersediaan data yang mudah di Akses. Dengan salah satu kriteria sampel adalah laporan keuangan yang telah diaudit terlebih dahulu.

\section{Instrumen Penelitian}

Instrumen yang digunakan berupa data nilai arus kas operasi, arus kas investasi, arus kas pendanaan, return on investment dan return saham selama 7 tahun yaitu dari tahun 2013 sampai dengan 2019.

\section{Teknik pengumpulan data}

Dalam penelitian ini ada 2 cara teknik pengumpulan data diantaranya yaitu :

Pertama, studi pustaka adalah pengumpulan data dengan cara mengadakan studi pustaka yang berkaitan dengan objek penelitian, untuk memperoleh bahan kepustakaan terutama teori yang mendukung penelitian ini. Kedua, Dokumentasi adalah alat pengumpulan data dengan cara melakukan pencatatan langsung melalui dokumen - dokumen arsip yaitu berupa laporan keuangan yang telah diaudit pada PT Mayora Indah Tbk.

\section{Teknik Analisis Data}

Teknik analisi Data yang digunakan yaitu Uji Asumsi Klasik meliputi Uji Normalitas data, Uji Multikolinearitas, Uji heteroskedastisitas dan uji Autokorelasi. Serta Analisis regresi linier berganda, analisis korelasi berganda, koefisien determinasi, Uji T dan Uji F.

\section{Hasil dan Pembahasan \\ Uji Normalitas Data \\ Gambar 1}

\section{Hasil Uji Normalitas}

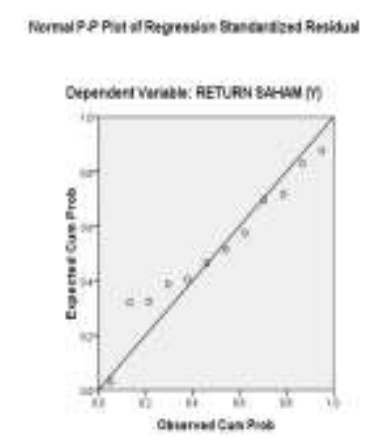

Sumber: data sekunder diolah, 2021 
Berdasarkan hasil pengujian diatas diperoleh bahwa titik - titik tersebut mengikuti garis diagonal maka kesimpulan uji normalitas berdistribusi normal.

\section{Uji Multikolinearitas}

\section{Tabel 1}

\section{Hasil Uji Multikolinearitas}

\begin{tabular}{|c|c|c|c|}
\hline Variabel & Tolerance & VIF & Keterangan \\
\hline $\begin{array}{l}\text { AKO } \\
(\mathrm{X} 1)\end{array}$ & .618 & 1.617 & $\begin{array}{c}\text { Tidak ada } \\
\text { multikolinearitas }\end{array}$ \\
\hline $\begin{array}{l}\text { AKI } \\
(\mathrm{X} 2)\end{array}$ & .745 & 1.342 & $\begin{array}{c}\text { Tidak ada } \\
\text { multikolinearitas }\end{array}$ \\
\hline $\begin{array}{l}\text { AKP } \\
\text { (X3) }\end{array}$ & .341 & 2.932 & $\begin{array}{c}\text { Tidak ada } \\
\text { multikolinearitas }\end{array}$ \\
\hline $\begin{array}{l}\text { ROI } \\
(\mathrm{X} 4)\end{array}$ & .390 & 2.564 & $\begin{array}{c}\text { Tidak ada } \\
\text { multikolinearitas }\end{array}$ \\
\hline
\end{tabular}

Sumber: data sekunder diolah, 2021

Berdasarkan tabel diatas diketahui semua variabel independen memiliki nilai tolerance > 0,100 dan nilai $\mathrm{VIF}<10,00$ sehingga dapat disimpulkan bahwa tidak ada gejala multikolinearitas.

\section{Uji Heteroskedastisitas}

\section{Gambar 2}

\section{Hasil Uji Heteroskedastisitas}

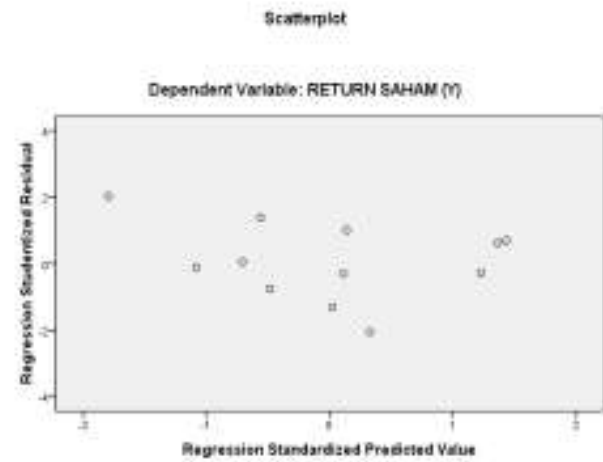

Sumber: data sekunder diolah, 2021

Berdasarkan gambar diatas bahwa titik titik tersebut random serta titik - titik menyebar diatas dan dibawah angka 0 pada sumbu Y. maka kesimpulan dari uji heteroskedastisitas yaitu tidak ada gejala heteroskedastisitas.

\section{Uji Autokorelasi}

Tabel 2

Hasil Uji Autokorelasi

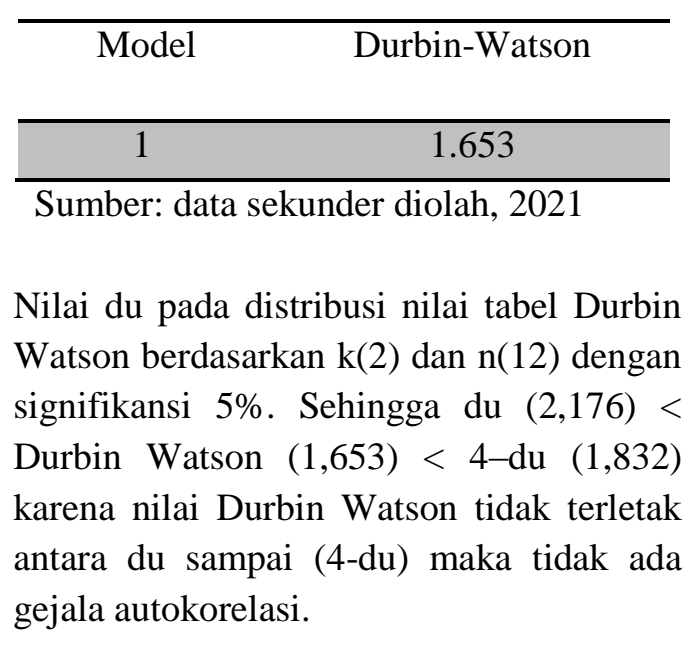

Analisis Regresi Linier Berganda

Tabel 3

Hasil Uji Regresi Linier Berganda 


\section{Analisis Korelasi Berganda}

\begin{tabular}{|c|c|c|}
\hline \multirow[t]{2}{*}{ Model } & \multicolumn{2}{|c|}{$\begin{array}{l}\text { Unstandardized } \\
\text { Coefficients } \\
\end{array}$} \\
\hline & $\mathrm{B}$ & Std. Error \\
\hline (Constant) & 2630.015 & 495.418 \\
\hline AKO (X1) & -4.990 & 45.240 \\
\hline AKI (X2) & 226.281 & 79.942 \\
\hline $\mathrm{AKP}(\mathrm{X} 3)$ & -2.362 & 11.502 \\
\hline \multirow{2}{*}{$\frac{\mathrm{ROI}(\mathrm{X} 4)}{\text { Sum }}$} & -178.450 & 96.892 \\
\hline & \multicolumn{2}{|c|}{ Sumber: data sekunder diolah, 202} \\
\hline \multicolumn{3}{|c|}{$\begin{array}{l}\text { Berdasarkan tabel } 3 \text { diatas } \\
\text { persamaan regresi linier berganda }\end{array}$} \\
\hline \multicolumn{3}{|c|}{$\mathrm{RS}=23630,015-4,990 \mathrm{AKO}+226,281 \mathrm{AKI}$} \\
\hline
\end{tabular}

Berdasarkan persamaan di atas, dapat diperoleh makna yaitu :

Pertama, Konstanta $\left(\beta_{0}\right)=23630,015$. jika nilai arus kas operasi, arus kas investasi, arus kas pendanaan dan return on investment dianggap konstan, maka nilai return saham naik sebesar 23630,015 .

Kedua, Arus kas operasi $\left(\beta_{1}\right)=-4,990$. Setiap penurunan arus kas operasi maka return saham mengalami penurunan sebesar $-4,990$.

Ketiga, Arus kas investasi $\left(\beta_{2}\right)=$ 226,281. Setiap kenaikan arus kas investasi maka return saham mengalamikenaikan sebesar 226,281.

Keempat, Arus kas pendanaan $\left(\beta_{3}\right)=$ 2,362. Setiap penurunan arus kas pendanaan maka return saham mengalami penurunan sebesar $-2,362$.

Kelima, Return on investment $\left(\beta_{4}\right)$ $=178,450$. Setiap kenaikan return on investment maka return saham mengalami kenaikan sebesar 178,450.
Tabel 4

Hasil Uji Korelasi Berganda

\begin{tabular}{cccc}
\hline Model & $\mathrm{R}$ & $\begin{array}{c}\mathrm{R} \\
\text { Square }\end{array}$ & $\begin{array}{c}\text { Adjusted } \\
\text { R Square }\end{array}$ \\
\hline 1 & $.819^{\mathrm{a}}$ & .671 & .483 \\
\hline
\end{tabular}

Sumber : data sekunder diolah, 2021.

Berdasarkan tabel diatas diperoleh nilai korelasi berganda sebesar 0,819 yang berarti bahwa tingkat keeratan hubungan antara arus kas dan profitabilitasterhadap return saham pada PT

Mayora Indah Tbk berada pada tingkat yang sangat kuat.

\section{Koefisien Determinasi}

Berdasarkan tabel 4 diatas fljperoleh nilai koefisien determinasi sebesar 0, FZ $_{2} 1$. Artinya kontribusi pengaruh arus $\mathrm{l}_{\mathrm{H}} \mathrm{S}$ dan rasio profitabilitas terhadap return $_{\mathrm{H}_{4}^{\text {saham }}} 67,1 \%$ dan sisanya sebesar 32,9\% (100\% - 67,1\%) dipengaruhi faktor lain yang tidak diteliti dalam penelitian ini.

Uji F

Tabel 5

Hasil Uji F

\begin{tabular}{ccc}
\hline Model & F & Sig. \\
& & \\
\hline $\begin{array}{c}\text { Regression } \\
\text { Residual } \\
\text { Total }\end{array}$ & 3.659 & .068 \\
\hline
\end{tabular}

Sumber: data sekunder diolah, 2021

Pada tabel diatas diperoleh F-hitung $(3,569)$ < F-tabel $(3,83)$ maka kesimpulan uji $\mathrm{F}$ simultan yaitu arus kas dan profitabilitas secara simultan tidak berpengaruh terhadap return saham. 
Uji T

\section{Tabel 6}

Hasil Uji T

\begin{tabular}{|c|c|c|c|c|}
\hline Variabel & $\begin{array}{l}\mathrm{t} \\
\text { itung }\end{array}$ & Sig. & Tabel & Ket. \\
\hline $\mathrm{AKO}(\mathrm{X} 1)$ & -.110 & .915 & 2,36462 & $\begin{array}{c}\mathrm{H}_{1} \\
\text { tidak } \\
\text { diterima }\end{array}$ \\
\hline AKI (X2) & 2.831 & .025 & 2,36462 & $\begin{array}{c}\mathrm{H}_{2} \\
\text { diterima }\end{array}$ \\
\hline $\mathrm{AKP}(\mathrm{X} 3)$ & -.205 & .843 & 2,36462 & $\begin{array}{c}\mathrm{H}_{3} \\
\text { tidak } \\
\text { diterima }\end{array}$ \\
\hline ROI (X4) & -1.842 & .108 & 2,36462 & $\begin{array}{l}\mathrm{H}_{4} \text { tidak } \\
\text { diterima }\end{array}$ \\
\hline
\end{tabular}

Sumber: data sekunder diolah, 2021

\section{Arus Kas Operasi (AKO) Terhadap} Return Saham

Berdasarkan hasil olah data statistik diketahui nilai t-hitung sebesar $-0,110<$ nilai t-tabel 2,36462 dengan nilai signifikansi 0915. Hal ini menunjukkan bahwa variabel arus kas operasi tidak berpengaruh signifikan terhadap return saham. Hal ini disebabkan karna investor tidak menggunakan arus kas operasi sebagai pertimbangan dalam mengambil keputusan investasinya. Selain itu diduga kandungan informasi arus kas operasi memberikan dukungan yang lemah bagi investor karena memang walaupun arus kas operasi merupakan faktor fundamental untuk menentukan investasi tetapi disisi lan juga ada faktor - faktor lain seperti kondisi ekonomi dan politik serta keamanan yang dapat mempengaruhi return saham namun tidak diteliti.

\section{Arus Kas Investasi (AKI) Terhadap Return Saham}

Berdasarkan hasil olah data statistik diketahui nilai t-hitung 2,831 > nilai ttabel 2,36462 dengan nilai signifikansi 0,025. Hal ini menunjukkan bahwa variabel arus kas investasi berpengaruh signifikan terhadap return saham. Hasil penelitian ini menunjukkan bahwa arus kas investasi berpengaruh dan signifikan terhadap return saham.Hal ini dapat diartikan bahwa besar kecilnya arus kas investasi dapat mempengaruhi peningkatan return saham sehingga dapat dikatakan bahwa investor merespon terhadap arus kas investasi.

\section{Arus Kas Pendanaan (AKP) Terhadap Return Saham}

Berdasarkan hasil olah data statistik diketahui nilai t-hitung $-0,205<$ nilai $\mathrm{t}$ tabel 2,36462 dengan nilai signifikansi 0,843 . Hal ini menunjukkan bahwa variabel arus kas pendanaan tidak berpengaruh signifikan terhadap return saham. Hal ini disebabkan karna investor belum menggunakan arus kas pendanaan sebagai bahan pertimbangan dalam

melakukan investasi dan beranggapan bahwa arus kas pendanaan yang tinggi kurang dianggap baik dalam kinerja perusahaan. Selain itu, informasi yang terkandung dalam arus kas pendanaan belum sepenuhnya digunakan sebagai dasar pengambilan keputusan dalam pasar modal.

\section{Return On Investmenrt (ROI) Terhadap Return Saham}

Berdasarkan hasil olah data statistik diketahui nilai $\mathrm{t}$ hitung $-1,842<$ nilai $\mathrm{t}$ - tabel 2,36462 
dengan nilai signifikansi 0,108. Hal ini menunjukkan bahwa variabel retun on investment tidak berpengaruh signifikan terhadap return saham. Hal ini disebabkan karna investor belum menggunakan Return On Investmenrt sebagai bahan pertimbangan dalam melakukan investasi dan belum menggunakan ROI sebagai alat dalam memprediksi tingkat return saham perusahaan.

\section{Kesimpulan}

Berdasarkan hasil penelitian, maka kesimpulan penelitian ini yaitu pertama, Berdasarkan hasil uji regresi secara parsial hanya variabel arus kas investasi yang berpengaruh signifikan terhadap return saham sedangkan variabel arus kas operasi, arus kas pendanaan dan return on investment tidak berpengaruh terhadap return saham. Kedua, Berdasarkan hasil uji regresi secara simultan tidak terdapat pengaruh yang signifikan variabel bebas arus kas operasi, arus kas investasi, arus kas pendanaan dan return on investment terhadap variabel terikat return saham. Ketiga, Ada hubungan yang positif antara variabel bebas arus kas operasi, arus kas investasi, arus kas pendanaan dan return on investment dengan variabel terikat return saham dan hubungannya yaitu sangat kuat. Keempat, besaran pengaruh persamaan modal memiliki koefisien determinasi sebesar 0,671 menunjukkan bahwa besarnya kontribusi arus kas operasi, arus kas investasi, arus kas pendanaan dan return on investment dengan return saham sebesar $67,1 \%$, sisanya dipengaruhi oleh faktor lain.

\section{Daftar Pustaka}

Basuki, B. (2017). PENGARUH ARUS KAS DAN PROFITABILITAS TERHADAP RETURN SAHAM (Pada Industri Dasar dan Kimia yang Terdaftar di Bursa Efek
Indonesia Periode 2010-2012). Competitive Jurnal Akuntansi Dan Keuangan, 1(2). https://doi.org/10.31000/competitive.v1i2.2 31

Dasuki, T. M. S. (2020). Pengaruh Arus Kas Operasi, Firm Size, Dan Momentum Terhadap Return Saham Pada Perusahaan Yang Terdaftar Dalam Indeks Lq 45 Periode 2014 - 2018 Di Bursa Efek Indonesia. Jurnal Akuntansi Keuangan Dan Sistem Informasi (JAKSI), 1(1), 81-100. https://ejournal.unma.ac.id/index.php/jaksi/ article/download/177/127

Endang Masitoh W., S. P. Y. C. (2017). Pengaruh Laba Akuntansi Dan Arus Kas Terhadap Return Saham Perusahaan Yang Listing Di Bei. Jurnal Akuntansi Dan Pajak, 16(01), 113-123. https://doi.org/10.29040/jap.v16i01.27

Kristanti, I. N. (2018). Analisis Pengaruh Arus Kas Operasi Dan Laba Akuntansi Terhadap Return Saham Perusahaan Peraih Investment Award (Best Issuers) Di Bursa Efek Indonesia. Jurnal Ilmiah Akuntansi Dan Keuangan, 7(2), 29-44. https://doi.org/10.32639/jiak.v7i2.217

LUBIS, I. S. L. (2020). Analisis Faktor Faktor (Roi, Arus Kas Investasi Dan Der), Yang Mempengaruhi Harga Saham Pada Perusahaan Manufacturing Di ... Jurnal Ilmiah Simantek, 4(3). https://simantek.sciencemakarioz.org/index. php/JIK/article/download/165/144

Maulita, D., \& Arifin, M. (2018). Pengaruh Return On Investment (ROI) Dan Earning Per Share (EPS) Terhadpa Return Saham Syariah (Studi Kasus Pada Perusahaan Manufaktur Sub Sektor Makanan dan Minuman Yang Terdaftar Pada Indeks Saham Syariah Indonesia Periode 20122016). Jurnal Manajemen, 8, 10-19. http://e-

jurnal.lppmunsera.org/index.php/JM/article/ view/659

Muharam, N. (2018). Perlindungan Hukum Bagi Investor dalam Pembelian Kembali Sahamnya. Pranata Hukum, 13(1), 59-71. https://doi.org/10.36448/pranatahukum.v13i 1.177 
Nurchayati, \& Nasaroh, S. (2017). Cash Flow Analysis on Stock Returns in Manufacturing Companies Food and Beverage Sub Sector on the Indonesia Stock Exchange. Jurnal Ilmiah Untag Semarang, 6(2), 127-134. http://jurnal.untagsmg.ac.id/index.php/sa/art icle/download/628/603

Oktavianti, O. (2018). Pengaruh Return on Investment (Roi), Earning Per Share (Eps) Dan Economic Value Added (Eva) Terhadap Return Saham Pada Perusahaan Otomotif Yang Terdaftar Di Bei Pada Tahun 2013-2016. Jurnal Bening, 5(2), 152. https://doi.org/10.33373/bening.v5i2.1458

Rahayu, A., \& Mahsuni, A. W. (2019). PENGARUH LABA BERSIH DAN ARUS KAS TERHADAP RETURN TERDAFTAR DI BURSA EFEK INDONESIA Oleh. Jurnal Ekonomi Dan Bisnis, 08(09), 56-68.

Sachiyudin, A. (2018). Analisis Pengaruh Laba Bersih, Arus Kas, Leverage, Dan Ukuran Perusahaan Terhadap Return Saham. Prosiding 2nd Business and Economics Conference In Utilizing of Modern Technology, 267-284.

Setyawan, B. (2020). Pengaruh Arus Kas Koperasi, Arus Kas Investasi, Arus Kas Pendanaan Dan Laba Akuntansi Terhasap Return Saham Pasa Emiten Sub Sektor Makanan Dan Minuman. Equilibrium: Jurnal Ilmiah Ekonomi, Manajemen Dan Akuntansi,

9(1). https://doi.org/10.35906/je001.v9i1.486 